\title{
EFFICIENCY OF SOME NEW INSECTICIDES ON COTTON BOLLWORMS, Pectinophora gossypiella (SAUND.) AND Earias insulana (BOISD.) \\ Saleh, A. A. ${ }^{1}$; Laila R. Elgohary ${ }^{1}$;W. M. Watson ${ }^{2}$ and A. S. Elabasy ${ }^{2}$ 1Pesticides Dept., Fac. of Agric., Mansoura Univ., Egypt \\ 2Plant protection, Research Institute, Agric. Research Center, Doki, Giza, Egypt
}

\begin{abstract}
Field experiments were conducted at Sakha Agricultural Research Station Farm during 2011 and 2012 cotton growing seasons to evaluate the efficacy commercial formulation of four insecticides, i.e., pyridalyl, emamectin benzoate, methomyl and methoxyfenozide against pink bollworm, Pectinophora gossypiella (Saund.) and spiny bollworm, Earias insulana (Boisd.). Pyridalyl and emamectin benzoate were the most efficient compounds during the two seasons. The treatments could be arranged descendingly according to the average reduction of two seasons as follows: pyridalyl $(52.21,50.78 \%)$, emamectin benzoate $(46.55,49.61 \%)$, methomyl $(38.49,37.82 \%)$ and methoxyfenozide $(34.10,31.90 \%)$ against pink and spiny bollworms. Also, the toxicity of these compounds was determined against $4^{\text {th }}$ instar larvae of spiny bollworm, $E$. insulana (Boisd.) using film residue assay method. The data revealed that emamectin benzoate was a superior potent compound followed by methoxyfenozide, pyridalyl and methomyl, with LC $_{50}$ values were 1.42, 14.21, 16.99 and 99.78 ppm, respectively.
\end{abstract}

Keywords: Cotton bollworms, emamectin benzoate, methoxyfenozide, methomyl, pyridalyl.

\section{INTRODUCTION}

In Egypt, cotton is one of the most important cash crops and represents more than half the income of two million small-scale farmers (Zidan et al., 2012). But cotton is attacked by many insect species. Cotton bollworms are the most destructive pests infesting cotton plants, pink bollworm (PBW), P. gossypiella (Saund.) and spiny bollworm (SBW), E. insulana (Boisd.) infest many cotton producing areas of the world and cause a severe reduction in cotton yield and quality (Lohar and Nahyoon, 1995).

Emamectin benzoate is a modified isolation of the soil microorganism, Streptomyces avermitilis. It affects the nervous system of arthropods by increasing chloride ion flux at the neuromuscular junction, resulting in cessation of feeding and irreversible paralysis. Also, it affects on GABA and glutamate-gated chloride channel agonist (Dunbar et al., 1998).

Methoxyfenozide is classified as a diacylhydrazine insecticide. It acts as ecdysone agonists with enormous potential for development as insect specific control agents with little or no effect on non-target species (Dhadialla and Carlson, 1998). Also, it provides effective control of a wide range of lepidopteran insects. The chemical upon absorption into the haemolymph of the insect, binds to the ecdysone receptor which initiates the moulting process. As the normal process disrupted, the insects prevented from 
Saleh, A. A. et al.

shedding its old cuticle. The larvae die of dehydration and starvation within 25 days (Kumar and Santharam, 2008).

Pyridalyl exhibit high insecticidal activity against Lepidoptera (Sakamoto and Umeda, 2003). It posses a certain type of toxicity for insect cells, it inhibited the cell growth (Satio et al., 2006).

The present study was conducted to evaluate the effect of the three novel insecticides (emamectin benzoate, methoxyfenozide, and pyridalyl) and the conventional one (methomyl) against pink bollworm and spiny bollworm under field and laboratory conditions.

\section{MATERIALS AND METHODS}

\section{Insecticides used:}

The insecticides used and their recommended rates of application per feddan were: Emamectin benzoate (Proclaim 5\% SG, 60g/fed.), Methoxyfenozide (Runner $24 \%$ SC, $150 \mathrm{~cm}^{3} / \mathrm{fed}$.), Methomyl (Lannate $90 \%$ SP, $300 \mathrm{~g} / \mathrm{fed}$.) and Pyridalyl (Pleo $50 \% \mathrm{EC}, 100 \mathrm{~cm}^{3} / \mathrm{fed}$.).

\section{Field experiment:}

Experiments were conducted during 2011 and 2012 cotton growing seasons at Sakha Agricultural Research Station Farm. The cultivated cotton variety was Giza 86 . Treatments were distributed in a randomized complete block design with four replicates for each treatment. The area of each replicate was one kirate $\left(175 \mathrm{~m}^{2}\right)$ and four kirate were used as untreated control. All agricultural processes were carried out as usual. Each of the tested insecticides was applied three times on the dates 10/8, 24/8 $\& 7 / 9 / 2011$ and $31 / 7,14 / 8$ and 28/8/2012. The insecticides were diluted with water $200 \mathrm{~L} /$ fed. and sprayed using a knapsack sprayer with one nozzle (Mode Cp3).

Samples of 100 green bolls per treatment ( 25 bolls for each replicate) were taken at random and dissected. Percent of infestation were estimated immediately before the first spray and then every week through out the period of experiment which extended from 9/8 to 21/9 (2011) and from 30/7 to 11/9 (2012). Henderson and Tilton equation (1955) was used to calculate the reduction percentage of infestation.

\section{Laboratory tests:}

The residual film method was used to determine the $\mathrm{LC}_{50}$ values of different insecticides. A series of concentrations (in acetone) for each insecticide was prepared on the active ingredient (a.i) based on ppm by diluting the commercial formulation, one milliliter of acetone solution of the toxicant under test was uniformity distributed on the surface of a Petri-dish (9 $\mathrm{cm}$ diameter). After complete dryness, five full-grown larvae ( $4^{\text {th }}$ instar larvae) of spiny bollworm were confined and left to dose themselves by crowling on the deposited film. The Petri-dish was covered and the mortality was counted and recorded after $24 \mathrm{hrs}$ of exposure. Three replicates (each of 5 larvae) were used for each concentration. Mortality percentages were corrected 
according to Abbott's formula (1925) and the LC $_{50}$ values were calculated (Finney, 1971).

\section{Statistical analysis:}

Statistical analysis of data was carried out according to Duncan multiple range test (Duncan, 1955) using Costate version 4.20 Cohort software. Mortality percentages were corrected according to Abbott's formula (1925) and the LC ${ }_{50}$ values were calculated (Finney, 1971) using « Ldp Line » software [http:// embark.tripod.com/ldpline.htm].

\section{RESULTS AND DISCUSSION}

The obtained results in Tables (1) showed the toxic effect of the tested insecticides against pink bollworm in 2011 and 2012 cotton seasons, when they were applied once, twice and triple. Based on the mean of reduction percentage in infestation, in two seasons, pyridalyl and emamectin benzoate were the most effective compounds as they caused (52.94, 51.48 $\%)$ and $(43.74,49.37 \%)$ reduction respectively, followed by methomyl causing $(38.25,38.74 \%)$ reduction. While the tested insecticide methoxyfenozide was the least effective recording (33.23, $34.96 \%)$.

Results in Table (2) showed the toxic effect of the same tested insecticides against spiny bollworm in 2011 and 2012 cotton seasons during three sprays. The obtained results showed that, mean of reduction percentage in infestation of spiny bollworm in 2011 season were 47.93, $47.93,33.47$ and $31.30 \%$ for pyridalyl, emamectin benzoate, methomyl and methoxyfenozide, respectively. In 2012, the percentage of reduction in spiny bollworm larval population was higher than in 2011 season and could be arranged descendingly as follows: pyridalyl (53.64\%), emamectin benzoate (51.29\%), methomyl (42.18\%) and methoxyfenozide (32.51\%).

Results in Table (3) show the susceptibility of the full-grown larvae of spiny bollworm to the four tested insecticides during 2012 cotton season. The obtained results indicated that the emamectin benzoate was a superior potent compound followed by methoxyfenozide and pyridalyl, while methomyl was the least toxic one. The $\mathrm{LC}_{50}$ values of emamectin benzoate, methoxyfenozide, pyridaly and methomyl were 1.42, 14.21, 16.99 and 99.78 ppm after $24 \mathrm{hrs}$ of exposure, respectively.

According to the toxicity index at $\mathrm{LC}_{50}$ level, emamectin benzoate was the most effective one (100.0\%), however methoxyfenozide and pyridalyl were $9.99-8.35 \%$ as toxic as emamectin benzoate, the rest toxicant was methomyl $1.42 \%$ as toxic as emamectin benzoate. 
Saleh, A. A. et al. 
J. Plant Prot. and Path., Mansoura Univ., Vol. 4 (7), July, 2013 2 
Saleh, A. A. et al.

These results agree with Nair et al., (2008), who reported that pyridalyl provided excellent control of the two bollworm species of cotton. Mohamed (2008) found that the new chemical insecticide Pyridalyl proved of highest efficacy for bollworms control. Also, Amer et al., (2012) mentioned that emamectin benzoate and pyridalyl exhibited various efficacy effect against the newly hatched larvae of $P$. gossypiella especially 3-day after treatment, where the susceptibility of the pest to the tested compounds was the highest compared with the other recorded investigated time. The tested compound, pyridalyl is more effective than emamectin benzoate against the newly hatched larvae, the $\mathrm{LC}_{50 \mathrm{~s}}$ were 12.51 and $3.222 \mathrm{ppm}$ for emamectin benzoate and pyridalyl at 3-day after treatment, followed by 2-day (LC 5018.59 and $8.542 \mathrm{ppm}), 1$-day $\left(\mathrm{LC}_{50}: 194.4\right.$ and $\left.48.6 \mathrm{ppm}\right)$ then one hour age $\left(\mathrm{LC}_{50}\right.$ : 2115.6 and $656.9 \mathrm{ppm}$ ) after treatment for emamectin benzoate and pyridalyl, respectively. Gupta et al., (2005) and Sontakke et al., (2007) reported that emamectin benzoate was the most potent treatment in reducing pink bollworm, P. gossypiella and spotted bollworm, Earias sp. and causing significantly higher yields. Also, Shekeban et al., (2010) reported that emamectin benzoate was the most toxic insecticide between the tested insecticides. Also, Massoud et al., (2011) found that emamectin benzoate was a superior potent compound by $\mathrm{LC}_{50} 0.001 \mathrm{ppm}$ followed by spinosad with $\mathrm{LC}_{50}$ of $0.0065 \mathrm{ppm}$.

It be concluded that the two compounds pyridalyl as a cell toxic compound and emamectin benzoate as a nervous system blockers play an important role to be a valuable addition in an integrated pest management programmes followed by methomyl and methoxyfenozide against cotton bollworms, $P$. gossypiella and E. insulana.

Table (3): Toxicity of tested insecticides against full-grown larvae of spiny bollworm, E. insulana.

\begin{tabular}{|c|c|c|c|c|c|}
\hline \multirow{2}{*}{ Insecticides } & \multirow{2}{*}{$\begin{array}{c}\mathrm{LC}_{50} \\
(\mathrm{ppm})\end{array}$} & \multicolumn{2}{|c|}{$95 \% \mathrm{FL}^{\mathrm{a}}$ of $\mathrm{LC}_{50}$} & \multirow{2}{*}{ Slope \pm SE } & \multirow{2}{*}{$\mathrm{Ti}^{\mathrm{b}}$} \\
\hline & & Lower & Upper & & \\
\hline Emamectin benzoate & 1.42 & 0.788 & 2.66 & $1.645 \pm 0.413$ & 100.0 \\
\hline Methoxyfenozide & 14.21 & 6.31 & 29.70 & $1.316 \pm 0.385$ & 9.99 \\
\hline Methomyl & 99 & 49.70 & 185.16 & 1.534 & 1.42 \\
\hline Pyridalyl & 16.99 & 8.46 & 30.66 & $1.583 \pm 0.411$ & 8.35 \\
\hline
\end{tabular}
the other tested compound $\times 100$

\section{REFERENCES}

Abbott, W. S. (1925). A method for computing the effectiveness of an insecticide. J. Econ. Entomol., 18: 265-267.

Amer, R.A.M., A.E. Hatem and A.M. Adly (2012). Effect of emamectin Benzoate and pyridalyl on some demographic aspects of the pink boll worm, Pectinophora gossypiella (Saunders). Egypt. J. Agric. Res., 90(2): 657-673. 
Dhadialla, S. and R.Lep. Carlson (1998). New insecticides with ecdystero-idal and juvenile hormone activity.Ann Rev.Entomol., 43: 545-569.

Dunbar, D. M.; D. S. Lawson; S. M. White; P. Nago Dugger and D. Richter (1998). Emamectin benzoate control of Heliothine complex and impacton beneficial arthropods. Procceding Beltwide cotton San Diego, California, Proceedings, USA.V2, PP 1116-1118.

Duncan, D.B. (1955). Multiple ranges and multiple F. test. Biometrics, 11:142.

Finney, D.J. (1971). Probit analysis, $3^{\text {rd }}$ Ed. Cambridge Univ. Press, London PP: 333.

Gupta, G.P.; M. Raghuraman; A. B. and B. Singh (2005). Field efficacy of newer insecticides against bollworms in cotton. Indian. J. Entomol., 67(1): 16-20.

Henderson, C.F. and E. W. Tilton (1955). Test with acaricides against the brown wheat mite. J. Econ. Entomol., 48: 157-161.

Kumar, K. and G. Santharam (2008). Toxicity of RH-2485 (Methoxyfenozide 20F) against Helicoverpa armigera (Hub.). Journal of Biopesticides., 1(2): 199-200.

Lohar, M. K. and Y. M. Nahyoon (1995). Comparative efficacy of Hostathion, Sumicidin and Sevin XLR against cotton bollworms Sarhad. J. Agric., 11(13): 363-368.

Massoud, M.A.; M.M.K. Shekeban; A.S.A. Saad; A.K. Mourad and S.R Meharb (2011). Cytotoxic effect of potential pesticides on the cerebral neurosecretory celles (CNSC) of pink bollworm, Pectinophora gossypiella (Saund.). Resistant Pest Management Newsletter., 20 (2): 34-39.

Mohamed, M.S. (2008). Inducing resistance of cotton plants against boll worms infestation. Ph. D. Thesis, Fac. Agric. Benha Univ, Zagazig.

Nair, N.; K. Sekh; A.K. Somchoudhury and P.P. Dhar (2008). Bioeffica-cy of pyridalyl 10 EC against the bollworms of cotton and its effect on natural enemies in West Bengal condition. J. Entomol. Res., 32(4): 313-315.

Sakamoto, N.; K. Umeda (2003). Research and development a novel insecticides of pyridalyl. Fine chemicals., 32(20): 35-44.

Satio, S.; T. Yoshiok and U. Kimitoshi (2006). Ultrastructural effects of pyridalyl, an insecticides agent, on epidermal cells of Spodoptera litura larvae and cultural insect cells Sf9. Pesticides Sci., 31(3): 335-338.

Shekeban, M. M. K.; A. S. A. Saad; A. Zaher and S. R. Mehareb (2010). The latent effect of certain insecticides on pink bollworm, Pectino-phora gossypiella, (Saund.). J. Adv. Agric. Res. (Fac. Ag. Saba Basha)., 15(1): 57-75.

Sontakke, B.K.; N. Das and L.K. Swain (2007). Bioefficacy of emamectin benzoate against bollworm complex in cotton. Ann. Pl. Protec. Sci ., 15: $1-3$. 
Saleh, A. A. et al.

Zidan, N. E. A.; J. B. El-Naggar; S. A. Aref and M. E. El-Dewy (2012). Field evaluation of different pesticides against cotton bollworms, Suckin insects and their side effects.J.American.Sci., 8(2):128-136.

$$
\begin{aligned}
& \text { كفاعة بعض المبيدات الحشرية الجديدة علي ديدان اللوز القرنفلية والثوكية }
\end{aligned}
$$

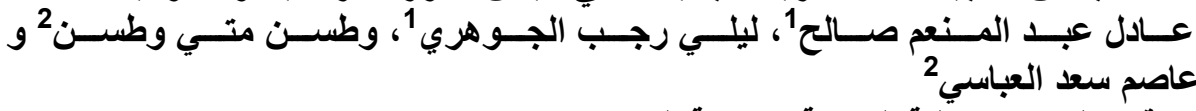

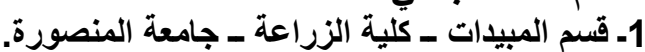

$$
\begin{aligned}
& \text { 2- معهد بحوث وقاية النباتات ـ مركز البحوث الزبة الزراعية ـ دقي ـ جيزه. }
\end{aligned}
$$

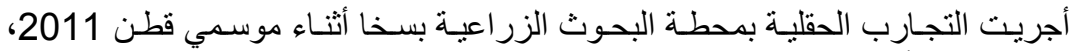

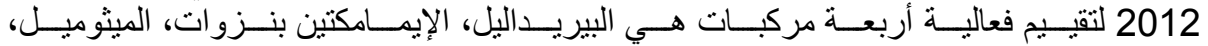

$$
\begin{aligned}
& \text { الميثوكسيفينوز ايد ضد يرقات دودة اللوز القرنية القفلية والثوكية. }
\end{aligned}
$$

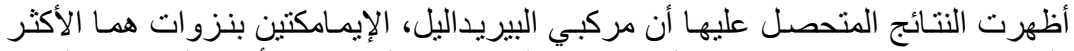

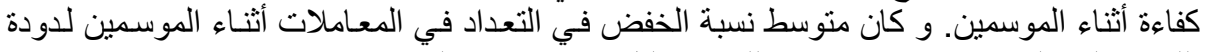

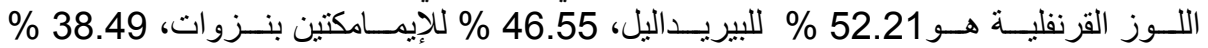

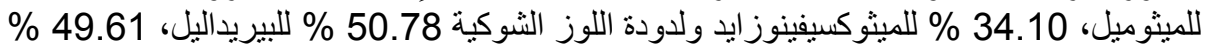

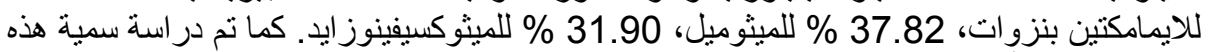

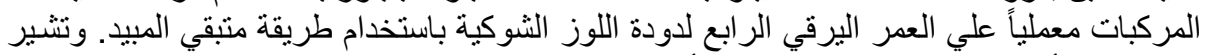

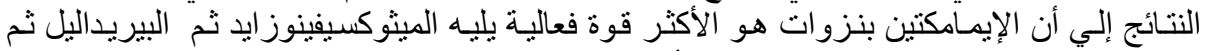

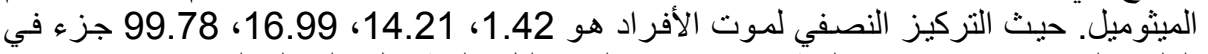

$$
\begin{aligned}
& \text { المليون للإيمامكتين بنزوات، الميثّوكسيفينوز ايد، البيريداليل، الميثوميل علي التو الي. }
\end{aligned}
$$


J. Plant Prot. and Path., Mansoura Univ., Vol. 4 (7), July, 2013 
Table (1): Reduction \% of pink bollworm ( $P$. gossypiella) larval population after treated with recommended rate of various insecticides during 2011 and 2012 cotton seasons.

\begin{tabular}{|c|c|c|c|c|c|c|c|c|c|c|c|c|c|c|c|}
\hline \multirow{3}{*}{ Treatments } & \multicolumn{6}{|c|}{ \% Reduction during 2011} & \multirow{3}{*}{ Mean } & \multicolumn{6}{|c|}{ \% Reduction during 2012} & \multirow{3}{*}{ Mean } & \multirow{3}{*}{$\begin{array}{c}\text { Average } \\
\text { reduction } \\
\text { of two } \\
\text { seasons }\end{array}$} \\
\hline & \multicolumn{2}{|c|}{$1^{\text {st }}$ Spray } & \multicolumn{2}{|c|}{$2^{\text {nd }}$ Spray } & \multicolumn{2}{|c|}{$3^{\text {rd }}$ Spray } & & \multicolumn{2}{|c|}{$1^{\text {st }}$ Spray } & \multicolumn{2}{|c|}{$2^{\text {nd }}$ Spray } & \multicolumn{2}{|c|}{$3^{\text {rd }}$ Spray } & & \\
\hline & $1 \mathrm{~W}$ & $2 \mathrm{~W}$ & $1 \mathrm{~W}$ & $2 \mathrm{~W}$ & $1 \mathrm{~W}$ & $2 \mathrm{~W}$ & & $1 \mathrm{~W}$ & $2 \mathrm{~W}$ & $1 \mathrm{~W}$ & $2 \mathrm{~W}$ & $1 \mathrm{~W}$ & $2 \mathrm{~W}$ & & \\
\hline $\begin{array}{l}\text { Emamectin } \\
\text { benzoate }\end{array}$ & 35.24 & 26.56 & 58.18 & 39.22 & 65.27 & 38.00 & $43.74 a b$ & 54.76 & 45.00 & 55.37 & 50.77 & 56.04 & 34.33 & $49.37 \mathrm{a}$ & $46.55 \mathrm{a}$ \\
\hline Methoxyfenozide & 32.33 & 26.56 & 41.78 & 32.33 & 48.62 & 17.76 & $33.23 \mathrm{~b}$ & 35.24 & 35.24 & 35.24 & 26.56 & 46.78 & 30.72 & $34.96 \mathrm{~b}$ & $34.10 \mathrm{~b}$ \\
\hline Methomyl & 35.24 & 26.56 & 41.78 & 32.33 & 57.29 & 36.33 & $38.25 \mathrm{~b}$ & 35.24 & 430.00 & 48.22 & 35.24 & 52.24 & 31.50 & $38.74 \mathrm{~b}$ & $38.49 \mathrm{~b}$ \\
\hline Pyridalyl & 61.89 & 58.89 & 58.18 & 53.31 & 57.29 & 28.11 & $52.94 \mathrm{a}$ & 54.76 & 45.00 & 54.76 & 50.77 & 56.04 & 47.58 & $51.48 \mathrm{a}$ & $52.21 \mathrm{a}$ \\
\hline
\end{tabular}

Means followed by the same letter (s) are not significantly different at the $5 \%$ level by Duncan (1955). 
Table (2): Reduction \% of spiny bollworm (E. insulana) larval population after treated with recommended rate of various insecticides during 2011 and 2012 cotton seasons.

\begin{tabular}{|c|c|c|c|c|c|c|c|c|c|c|c|c|c|c|c|}
\hline \multirow{3}{*}{ Treatments } & \multicolumn{6}{|c|}{ \% Reduction during 2011} & \multirow{3}{*}{ Mean } & \multicolumn{6}{|c|}{ \% Reduction during 2012} & \multirow[b]{3}{*}{ Mean } & \multirow{3}{*}{$\begin{array}{c}\text { Average } \\
\text { reduction } \\
\text { of two } \\
\text { seasons }\end{array}$} \\
\hline & \multicolumn{2}{|c|}{$1^{\text {st }}$ Spray } & \multicolumn{2}{|c|}{$2^{\text {nd }}$ Spray } & \multicolumn{2}{|c|}{$3^{\text {rd }}$ Spray } & & \multicolumn{2}{|c|}{$1^{\text {st }}$ Spray } & \multicolumn{2}{|c|}{$2^{\text {nd }}$ Spray } & \multicolumn{2}{|c|}{$3^{\text {rd }}$ Spray } & & \\
\hline & $1 \mathrm{~W}$ & $2 \mathrm{~W}$ & $1 \mathrm{~W}$ & $2 \mathrm{~W}$ & $1 \mathrm{~W}$ & $2 \mathrm{~W}$ & & $1 \mathrm{~W}$ & $2 \mathrm{~W}$ & $1 \mathrm{~W}$ & $2 \mathrm{~W}$ & $1 \mathrm{~W}$ & $2 \mathrm{~W}$ & & \\
\hline $\begin{array}{l}\text { Emamectin } \\
\text { benzoate }\end{array}$ & 54.76 & 40.92 & 53.73 & 40.22 & 50.77 & 747.18 & $47.93 \mathrm{a}$ & 66.27 & 58.89 & 52.53 & 41.78 & 49.08 & 39.23 & $51.29 \mathrm{a}$ & $49.61 \mathrm{a}$ \\
\hline Methoxyfenozide & 35.24 & 22.22 & 46.89 & 28.11 & 39.23 & 316.11 & $31.30 \mathrm{~b}$ & 31.50 & 18.44 & 45.34 & 34.45 & 40.16 & 25.18 & $32.51 \mathrm{c}$ & $31.90 \mathrm{~b}$ \\
\hline Methomyl & 45.00 & 22.22 & 53.73 & 20.70 & 43.11 & 16.11 & $33.47 \mathrm{~b}$ & 52.89 & 39.23 & 52.53 & 41.78 & 36.69 & 30.00 & $42.18 \mathrm{~b}$ & $37.82 \mathrm{~b}$ \\
\hline Pyridalyl & 54.76 & 40.92 & 53.73 & 40.22 & 50.77 & 747.18 & $47.93 \mathrm{a}$ & 62.10 & 50.77 & 70.54 & 48.22 & 55.49 & 34.76 & $53.64 \mathrm{a}$ & $50.78 \mathrm{a}$ \\
\hline
\end{tabular}

Means followed by the same letter (s) are not significantly different at the $5 \%$ level by Duncan (1955). 
Saleh, A. A. et al. 